\title{
Evaluación de cinco dosis de vermicomposta en el cultivo de tomate (Solanum lycopersicum) en Sinaloa, México*
}

\author{
Evaluation of five vermicompost doses in tomato \\ (Solanum lycopersicum) cultivation in Sinaloa, Mexico
}

\begin{abstract}
Hugo Rubili Roblero Ramírez, Eusebio Nava Pérez, Wenceslao Valenzuela Quiñónez, Jesús Ricardo Camacho Báez y Gerardo Rodríguez-Quiroz ${ }^{1 \S}$

${ }^{1}$ Centro Interdisciplinario de Investigación para el Desarrollo Integral Regional-Unidad Sinaloa. Instituto Politécnico Nacional. Blvd. Juan de Dios Bátiz Paredes No. 250 , Guasave, Sinaloa,México.81101.Tel:687-872 9626.(douglas_coby@hotmail.com; enavap@ipn.mx; wvalenzu@ipn.mx;jbaez@ipn.mx).`Autor para correspondencia: grquiroz@ipn.mx.
\end{abstract}

\section{Resumen}

Los excesos de agroquímicos disminuyen la productividad de los suelos agrícolas, mientras que los fertilizantes de origen orgánico mejoran sus propiedades físico-químicas. La vermicomposta es una alternativa viable para mejorar la estructura y cantidad de nutrientes del suelo, por lo cual el objetivo de este estudio fue evaluar distintas dosis de vermicomposta en el cultivo de tomate (Solanum lycopersicum L.) del norte de Sinaloa. Se probaron: 0, 500, $1000,1600,2000$ y $4000 \mathrm{~kg} \mathrm{ha}^{-1}$ de vermicomposta $\mathrm{y}$ un testigo, en un diseño completamente al azar con tres repeticiones por tratamiento. Las variables estimadas fueron, tamaño, número y peso de fruto. El tomate abonado con más de $4000 \mathrm{~kg} \mathrm{ha}^{-1}$ de vermicomposta incrementó significativamente el número y tamaño del fruto en la planta, de ahí que se considera una opción viable para su utilización en cultivos comerciales de tomates.

Palabras clave: fertilización, floración, fruto, nutrición, vermicomposta.

El uso de la lombriz (Eisenia foetida Savigny, 1826) es una alternativa ecológica para transformar los recursos orgánicos en descomposición y mejorar la calidad de los suelos

\section{Abstract}

The excessive use of agrochemicals decrease productivity of agricultural soils, while organic fertilizers improve their physicochemical properties. Vermicompost is a viable alternative for improving the structure and amount of nutrients in the soil, therefore the aim of this study was to evaluate different vermicompost doses in tomato crops (Solanum lycopersicum L.) in northern Sinaloa. Vermicompost doses of 0, 500, 1 000, 1 600, 2000 and 4 $000 \mathrm{~kg} \mathrm{ha}^{-1}$ were tested including a control, in a completely randomized design with three replicates per treatment. The estimated variables were fruit size, number and weight. The addition of more than $4000 \mathrm{~kg} \mathrm{ha}^{-1}$ of vermicompost significantly increased the fruit number and size in tomato plants hence it is considered a viable option for use in commercial tomato crops.

Keywords: fertilization, flowering, fruit, nutrition, vermicompost.

The use of the earthworm (Eisenia foetida Savigny, 1826) is an environmentally friendly alternative to transform organic resources in decomposition and improve the quality of agricultural soils (Atiyeh et al., 2000). Plants develop in

\footnotetext{
* Recibido: enero de 2014

Aceptado: marzo de 2014
} 
agrícolas (Atiyeh etal., 2000). Las plantas se desarrollan en un sistema complejo donde un sustrato adecuado presenta en su estructura una alta porosidad, aireación y retención de agua (Olivares-Campos et al., 2012).

La vermicomposta tiene un efecto directo sobre el crecimiento de las plantas, y es un producto con gran potencial comercial (Atiyeh et al., 2002). Está formada por una mezcla química de sustancias minerales compuestas por bajas cantidades de sales que tienen una gran capacidad de intercambio iónico (Albanell et al., 1988), y aportan sustancias reguladoras del crecimiento de la planta (Tomati et al., 1990). Éstas sustancias activas, como los nitratos, fósforo y agregados solubles (potasio, calcio y magnesio), son fáciles de asimilar por las plantas (Orozco et al., 1996).

Ghosh et al.(1999) señalan que la mezcla de vermicomposta con fertilizantes inorgánicos aumentan el rendimiento de los cultivos, comparados con aquellos que sólo usan estos últimos; además, su aplicación mejora la calidad de la presentación de los productos hortícolas (Chakraborty et al., 2008) y el nivel de los nutrientes es más alto que el de cultivos tradicionales (Kale, 1998). En el proceso de lombricomposteo muchos nutrientes son cambiados a su forma más simples, lo que facilita su absorción por la planta (Chanda et al., 2011). Por ello, el objetivo de éste estudio fue evaluar distintas dosis de vermicomposta para el cultivo de tomate en un suelo con baja concentración de materia orgánica impactado por largos periodos de fertilización inorgánica del norte de Sinaloa.

En éste experimento se utilizó un abono orgánico (vermicomposta) a base de estiércol de ganado vacuno y desechos orgánicos de cocina, en una proporción 9:1, y un fertilizante inorgánico como fuente de nitrógeno (urea $46 \%$ ). El abono orgánico se lombricomposteó por seis meses. Se utilizó plántula de la variedad Missouri (Solanum lycopersicum L.) producidas en el invernadero del Centro Interdisciplinario de Investigación para el Desarrollo Integral de la Región, Unidad Sinaloa (CIIDIR-IPN) ubicado en Guasave, Sinaloa, México. El experimento se realizó durante el ciclo agrícola otoño-invierno en las áreas experimentales del CIIDIR-IPN. El material se trasplantó cuando las plantas tenían 40 días de germinación.

En el experimento de campo se evaluaron seis tratamientos. Los tratamientos fueron de: $0,500,1000,1600,2000$ y 4000 $\mathrm{kg} \mathrm{ha}^{-1}$ vermicomposta. A cada uno de los tratamientos se les agregó $600 \mathrm{~kg} \mathrm{ha}^{-1}$ de urea. El diseño utilizado fue en bloques a complex system where a suitable substrate has a structure with high porosity, aeration and water retention (OlivaresCampos et al., 2012).

Vermicompost (VC) has a direct effect on plant growth, and it is a product with great commercial potential (Atiyeh et al., 2002). It consists of a chemical mixture of minerals composed of low amounts of salts having a large ion exchange capacity (Albanell et al., 1988), and provide substances involved in plant growth regulation (Tomati et al., 1990). These active substances, such as nitrates, phosphorus and soluble aggregates (potassium, calcium and magnesium), are easily assimilated by plants (Orozco et al., 1996).

Ghosh et al. (1999) indicate that the mixture of vermicompost with inorganic fertilizers increase crop yields, compared to those who only use the latter; (Chakraborty et al., 2008) its application also improves the quality of vegetables and nutrient levels are higher than in traditional crops (Kale, 1998). In the vermicomposting process many nutrients are changed to their simplest form, facilitating its absorption by the plant (Chanda et al., 2011). Therefore, the objective of this study was to evaluate different vermicompost doses for tomato cultivation in soil with low organic matter concentration impacted by long periods of inorganic fertilization in northern Sinaloa.

In this experiment an organic fertilizer (vermicompost) based on cow manure and organic kitchen waste in a 9:1 ratio, and inorganic fertilizer as a nitrogen source $(46 \%$ urea) was used. The organic fertilizer was vermicomposted for six months. Seedlings of the Missouri (Solanum lycopersicum L.) variety were used, which were produced in the greenhouse of the Interdisciplinary Research Centre for Integral Development of the Region(CIIDIR-IPN), Sinaloa Unit located in Guasave, Sinaloa, Mexico was used. The experiment was conducted during the fall-winter crop cycle in the experimental areas of CIIDIR -IPN. Plant materials were transplanted 40 days after germination.

In the field experiment six treatments were evaluated. The treatments were: $0,500,1000,1600,2000$ and $4000 \mathrm{~kg}$ $\mathrm{VC} \mathrm{ha}{ }^{-1}$. Each of the treatments were added $600 \mathrm{~kg} \mathrm{ha}^{-1}$ of urea. The design was a randomized complete block design with three replications. The vermicompost was applied in two portions, the first portion three days before planting, applied on the transplantation site and the second portion after 45 days, the fertilizer was added into a hole made on 
completos al azar con tres repeticiones. La vermicomposta se aplicó en dos porciones; la primera porción tres días antes de la plantación colocándola en el sitio del trasplante y la segunda porción a los 45 días colocando el abono en un orificio que se realizó a un lado de las plantas, el cual posteriormente se tapo con el mismo suelo del cultivo. El riego fue por goteo cada tercer día, durante $3 \mathrm{~h}$ consecutivas. Las parcelas experimentales se componían de cinco surcos de $10 \mathrm{~m}$ de largo y separadas entre hileras a $1.50 \mathrm{~m}$ entre sí. En cada uno de los surcos se sembraron tres plántulas de tomate por metro lineal.

El muestreo se realizó tomando en forma aleatoria cinco plantas de tomate por repetición. Se realizaron tres muestreos a los 40, 65 y 100 días del trasplante, donde se contó el número de frutos, el tamaño del fruto en centímetros el cual se midió con un calibre de anillas modelo CAL50-80 y peso del fruto en gramos utilizando una balanza analítica (plus OHAUS AP210). El experimento tuvo una duración 100 días. Los datos se sometieron a un análisis de varianza (ANEVA $p \leq 0.05$ ) y cuando fue pertinente, las medias se compararon mediante la prueba de Tukey $(p \leq 0.05)$; dichos análisis se llevaron al cabo mediante el paquete Statistica.

Durante los muestreos se observó que los primeros frutos aparecieron en la dosis de $4000 \mathrm{~kg}^{\circ} \mathrm{mb} \mathrm{ha}^{-1}$ con respecto al resto de los demás tratamientos. Según Togun y Akanbi (2003), los primeros frutos aparecen en un tiempo relativamente corto a partir de la primera floración cuando el contenido de nutrientes en el suelo es alto y diverso. El número de frutos/planta al final del experimento en la dosis de $4000 \mathrm{~kg} \mathrm{lomb} \mathrm{ha}{ }^{-1}$ fue de 170, teniendo una diferencia significa con respecto al tratamiento de $0 \mathrm{~kg}$ lomb ha ${ }^{-1}$ que fue de 132 frutos/planta (Cuadro 1). En las demás dosis, el número de frutos fue menor a los 120 tomates por planta.

Este resultado coincide con lo reportado por Togun y Akanbi (2003), quien menciona que el número de frutos de tomate por planta con concentraciones $4000 \mathrm{~kg}$ lomb ha ${ }^{-1}$ fue $\sim 20 \%$ mayor que el tratamiento de $0 \mathrm{~kg} \mathrm{lomb} \mathrm{ha}^{-1}$, lo que la aplicación de estas concentraciones de vermicomposta son una respuesta correcta a las necesidades nutricionales de la planta.

En lo que respecta al peso y tamaño de los frutos de tomate, las plantas de $4000 \mathrm{~kg}$ lomb ha-1 en un periodo de seis semanas pasaron de los $\sim 3000 \mathrm{a} \sim 20000 \mathrm{~g} /$ planta (Cuadro 2). Durante el primer muestreo los pesos fueron similares por arriba de $\operatorname{los} \sim 2000 \mathrm{~g} /$ planta entre los tratamientos exceptuando el de $500 \mathrm{~kg}$ lomb ha-1 que fue de $\sim 1600 \mathrm{~g} /$ planta. one side of the plants, and covered with the same cultivation soil. Drip irrigation was performed every third day for 3 consecutive hours. Experimental plots consisted of five rows $10 \mathrm{~m}$ long spaced at $1.50 \mathrm{~m}$. In each of the grooves three tomato seedlings were planted per meter.

Sampling was done randomly taking five tomato plants per replication. Three samplings were performed at 40,65 and 100 days after transplantation, the number of fruits were counted, fruit size was measured in inches with a CAL50-80 fruit caliper and fruit weight in grams using an analytical balance (OHAUS plus AP210). The experiment lasted 100 days. Data were subjected to analysis of variance ( $p \leq 0.05$ ANOVA) and when required, the means were compared by the Tukey test $(p \leq 0.05)$, these analyzes were carried out using the Statistica package.

During sampling it was observed that the first fruits appeared at the dose of $4000 \mathrm{~kg} \mathrm{VC} \mathrm{ha}^{-1}$ compared to the other treatments. Togun and Akanbi (2003) indicate that the first fruits appear in a relatively short time after the first flowering when nutrient content in the soil is high and diverse. The number of fruits/plant at the end of the experiment at the dose of $4000 \mathrm{~kg} \mathrm{VCha}^{-1}$ was 170 , showing a significant difference with respect to the treatment of $0 \mathrm{~kg} \mathrm{VC} \mathrm{ha}^{-1}$ which was 132 fruits / plant (Table 1). In other doses, the number of fruits was less than 120 tomatoes per plant.

Cuadro 1. Número promedio de frutos producidos por planta en cada tratamiento durante todo el ciclo de cultivo.

Table 1. Average number of fruits produced per plant in each treatment throughout the crop cycle.

\begin{tabular}{cccc}
\hline & \multicolumn{3}{c}{ Muestra (días) } \\
\cline { 2 - 4 } Dosis $\left(\mathrm{kg} \mathrm{ha}^{-1}\right)$ & 40 & 65 & 100 \\
\hline 4000 & $29 \pm 3^{\mathrm{a}}$ & $82 \pm 7^{\mathrm{a}}$ & $170 \pm 20^{\mathrm{a}}$ \\
2000 & $24 \pm 4^{\mathrm{ab}}$ & $68 \pm 7^{\mathrm{bc}}$ & $124 \pm 25^{\mathrm{c}}$ \\
1600 & $25 \pm 4^{\mathrm{ab}}$ & $74 \pm 7^{\mathrm{b}}$ & $112 \pm 25^{\mathrm{d}}$ \\
1000 & $22 \pm 4^{\mathrm{ab}}$ & $64 \pm 6^{\mathrm{c}}$ & $105 \pm 24^{\mathrm{e}}$ \\
500 & $18 \pm 3^{\mathrm{b}}$ & $74 \pm 7^{\mathrm{b}}$ & $103 \pm 24^{\mathrm{e}}$ \\
0 & $25 \pm 4^{\mathrm{b}}$ & $81 \pm 7^{\mathrm{ab}}$ & $132 \pm 25^{\mathrm{b}}$ \\
\hline Promedios con letra diferente son significativamente diferentes $(p \leq 0.05)$.
\end{tabular}

This result agrees with that reported by Togun and Akanbi (2003), who mentions that the number of tomato fruits per plant at concentrations of $4000 \mathrm{VC} \mathrm{kg} \mathrm{ha}^{-1}$ was $\sim 20 \%$ higher than the $0 \mathrm{~kg} \mathrm{VC} \mathrm{ha}^{-1}$ treatment, thus these vermicompost concentrations meet the nutritional requirements of the plant. 
Durante el segundo muestreo, las plantas con la dosis de $1600 \mathrm{~kg}$ lomb ha-1 registraron el mayor peso con el menor número de frutos. Para el tercer muestreo, la dosis de 4000 $\mathrm{kg}$ lomb ha ${ }^{-1}$ tuvo producción promedio de $\sim 20000 \mathrm{~g} /$ planta, mostrando una diferencia significativa, mayor a los $\sim 5000$ $\mathrm{g} /$ planta sobre el control y de $\sim 7000 \mathrm{~g} /$ planta con respecto a los demás tratamientos. Esta diferencia se debe al número de frutos y al peso promedio del fruto por planta. El fruto con mayor peso se encontró en la dosis de $500 \mathrm{~kg}_{\text {lomb ha-1 }} \mathrm{con}$ un peso de $\sim 245 \mathrm{~g}$ y el de menor peso fue en $0 \mathrm{~kg}$ lomb ha ${ }^{-1}$ con $\sim 64.62 \mathrm{~g}$ del último conteo. De acuerdo con Akanbi et al. (2000) y Shankar et al. (2012).

Las cantidades de nutrientes dispuestos en la vermicomposta favorecen el peso y volumen de los tomates, y a diferencia de lo que reportan Maynard (1995) y Togun y Akanbi (2003), la producción total de frutos en las dosis más altas en comparación del control alcanzan mayor producción hasta de $\sim 5000 \mathrm{~g}$, confirmando quela vermicomposta complementala calidad de nutrientes que requiere la planta para su desarrollo. De acuerdo a lo reportado por Togun y Akanbi (2003), los frutos de tomate fertilizados con vermicomposta alcanzan un peso individual promedio de $\sim 120 \mathrm{~g}$, ya que los nutrientes disponibles para la planta provenientes de la vermicomposta favorecen la producción de frutos de mayor peso y tamaño (Shankar et al., 2012). Además, las altas dosis de vermicompostas mantienen un nivel adecuado de $\mathrm{pH}$ y contenido de sales, lo que favorece las condiciones físicas del suelo sean mejores para un mejor desarrollo de las plantas(Lazcano et al.,2009).Éstos resultados difieren con lo reportado por Domínguez et al. (2010) los cuales mencionan que a mayores concentraciones de las sustancias húmicas mayor será el crecimiento de las plantas debido a un incremento de la respuesta hormonal de la planta, ya que se observó una menor producción de frutos en las dosis intermedias de vermicomposta.

Porotra parte, en el tamaño del fruto, las dosis de 1000,1600 y 2 $000 \mathrm{~kg}$ lomb ha ${ }^{-1}$ presentaron frutos de $4 \mathrm{~cm}$ de diámetro y todas las dosis excepto la de $1600 \mathrm{~kg}$ lomb ha $^{-1}$ produjeron frutos de 7 $\mathrm{cm}$ (Cuadro 3). En la dosis de $0 \mathrm{~kg}$ lomb ha ${ }^{-1} 75 \%$ de los frutos está entre los 6 y $7 \mathrm{~cm}$ siendola dosis con la mayoría de sus frutos en las tallas grandes. En aquellas plantas conconcentracionesde vermicomposta alto se cosecharon en mayor cantidad tomates de $\sim 6 \mathrm{~cm}$, excepto en la dosis de 2000 que la mayor parte de su fruto estuvo por debajo de la medida $5.6 \mathrm{~cm}$.

El efecto de vermicomposta tuvo una influencia sobre el peso y tamaño del tomate, ya que los nutrientes esenciales en la vermicompostas aplicadas son similares a los reportados
With regard to the weight and size of tomato fruits, plants with $4000 \mathrm{~kg} \mathrm{VC} \mathrm{ha}^{-1}$ increased from $\sim 3000$ to $\sim 20000 \mathrm{~g} /$ plant over a period of six weeks (Table 2). During the first sampling weights were similar above the $\sim 2000 \mathrm{~g} / \mathrm{plant}$ between treatments except for the $500 \mathrm{~kg} \mathrm{VC} \mathrm{ha}^{-1}$ which was $\sim 1600 \mathrm{~g} /$ plant.

Cuadro 2. Peso promedio de fruto por planta en gramos. Table 2. Average fruit weight per plant in grams.

\begin{tabular}{cccc}
\hline & \multicolumn{3}{c}{ Muestreo (días) } \\
\cline { 2 - 4 } Dosis & 40 & 65 & 100 \\
\hline 4000 & $2857 \pm 366^{\mathrm{a}}$ & $7895 \pm 856^{\mathrm{b}}$ & $19978 \pm 2653^{\mathrm{a}}$ \\
2000 & $2187 \pm 165^{\mathrm{b}}$ & $6145 \pm 693^{\mathrm{c}}$ & $12444 \pm 3422^{\mathrm{c}}$ \\
1600 & $2082 \pm 112^{\mathrm{b}}$ & $8695 \pm 790^{\mathrm{a}}$ & $11418 \pm 3375^{\mathrm{d}}$ \\
1000 & $2379 \pm 414^{\mathrm{b}}$ & $7790 \pm 858^{\mathrm{b}}$ & $11679 \pm 3390^{\mathrm{d}}$ \\
500 & $1607 \pm 356^{\mathrm{c}}$ & $7445 \pm 555^{\mathrm{bc}}$ & $10650 \pm 3317^{\mathrm{e}}$ \\
0 & $2434 \pm 212^{\mathrm{ab}}$ & $8110 \pm 847^{\mathrm{ab}}$ & $14028 \pm 3429^{\mathrm{b}}$ \\
\hline Promedios con letra diferente son significativamente diferentes $(p \leq 0.05)$.
\end{tabular}

During the second sampling, the plants with the $1600 \mathrm{~kg}$ $\mathrm{VC} \mathrm{ha}^{-1}$ dose recorded the highest weight with the least number of fruits. For the third sampling, the $4000 \mathrm{~kg} \mathrm{VCha}^{-1}$ dose averaged a production of $\sim 20000 \mathrm{~g} /$ plant, showing a significant difference, greater than $\sim 5000 \mathrm{~g} /$ plant over the control and $\sim 7000 \mathrm{~g} /$ plant relative to the other treatments. This difference is due to the number of fruits and average fruit weight per plant. The fruit with the highest weight was found in the $500 \mathrm{~kg} \mathrm{VC} \mathrm{ha}^{-1}$ dose weighing $\sim 245 \mathrm{~g}$ and the lower weight was at $0 \mathrm{~kg} \mathrm{VC} \mathrm{ha}^{-1}$ with $\sim 64.62 \mathrm{~g}$ of the last count. This is in agreement with Akanbi et al. (2000) and Shankar et al. (2012).

The amounts of nutrients present in vermicompost increase the tomatoes weight and volume, and unlike reports from Maynard (1995) and Togun and Akanbi (2003), total fruit production in the higher doses compared to control increase production up to $\sim 5000 \mathrm{~g}$, confirming that vermicompost complements the nutrients quality required for plant development. According to reports from Togun and Akanbi (2003), tomato fruits fertilized with vermicompost reach an average individual weight of $\sim 120 \mathrm{~g}$, because the nutrients available to the plant from vermicompost favor the production of larger and heavier fruits (Shankar et al., 2012). In addition, high doses of vermicompost maintain an adequate $\mathrm{pH}$ level and salt content, which improves soil physical conditions promoting plant development (Lazcano et al., 2009). These results differ from those reported by Domínguez et al. (2010) who state that at higher concentrations of humic substances there will be greater 
por Atiyeh et al. (2002) y Shankar et al. (2012), los cuales mencionan que las vermicompostas proporcionan los nutrientes necesarios para un buen desarrollo de la planta. El mejoramiento estructural del suelo cultivable favorece la actividad de los microorganismos presentes, los cuales influyen en el intercambio de los nutrientes y la viabilidad potencial de la planta para crecer y aumentar el volumen de producción de tomate (Alarcón y Ferrera-Cerrato, 2000; Arancon et al. 2004, 2006). Los nutrientes presentes en un medio como la vermicomposta es asimilado por la planta en mayor concentración al encontrarse más biodisponibles como se observa en el presente estudio, por ello ayuda al crecimiento y desarrollo, en un tiempo relativamente corto, propiciando un inicio más temprano de la formación y producción de fruto en comparación con las plantas control.

El efecto de la vermicomposta sobre el desarrollo del tomate influyó de manera importante sobre el rendimiento de las plantas incrementando el número de frutos y su peso. Las plantas con la dosis de $4000 \mathrm{~kg}_{\text {lomb }} \mathrm{ha}^{-1}$ de vermicomposta tuvieron un comportamiento superior a las plantas del tratamiento testigo. La vermicomposta puede ser un excelente fertilizante de apoyo al fertilizante químico ya que permite obtener un mayor rendimiento y frutos de mayor calidad tanto para el mercado nacional como internacional, aunque haría falta hacer un análisis económico para considerar a la vermicomposta como un producto viable al cultivo del tomate.

\section{Agradecimientos}

Loa autores agradecen al Consejo Estatal de Ciencia y Tecnología (COECYT) del estado de Sinaloa por su apoyo económico en la realización de éste proyecto y al Instituto Politécnico Nacional (IPN), por las facilidades otorgadas para la realización del estudio. A Emilio López García (q.e.p.d.), Félix López García, Eustaquio Tirzo Castro y Paulino Castro por su ayuda desinteresada en el desarrollo de este trabajo de investigación.

\section{Literatura citada}

Albanell, E.; Plaixats, J. and Cabrero, T. 1988. Chemical changes during vermicomposting (Eiseniafetida) of sheep manure mixed with cotton industrial wastes. Biol. Fertility Soil. 6:266-269.

Alarcón, A. y Ferrera-Cerrato, R. 2000. Biofertilizantes: importancia y utilización en la agricultura. Agric. Téc. Méx. 26:191-203. plant growth due to an increased hormonal response from the plant; since a lower fruit production was observed in the intermediate vermicompost doses.

Concerning fruit size, the 1000,1600 and $2000 \mathrm{~kg} \mathrm{VCha}^{-1}$ doses showed fruits of $4 \mathrm{~cm}$ in diameter and all doses except the $1600 \mathrm{~kg} \mathrm{VC} \mathrm{ha}^{-1}$ produced fruits of $7 \mathrm{~cm}$ (Table 3 ). In the $0 \mathrm{~kg} \mathrm{VC} \mathrm{ha}{ }^{-1}$ dose, $75 \%$ of the fruits is between 6 and $7 \mathrm{~cm}$ being the dose with most fruits in large sizes. In those plants with high vermicompost concentrations a greater number of tomatoes of $\sim 6 \mathrm{~cm}$ were harvested, except for the 2000 $\mathrm{kg} \mathrm{VC} \mathrm{ha-1}$ dose in which most fruits were below $5.6 \mathrm{~cm}$.

\section{Cuadro 3. Tamaño de frutos de tomate producido por dosis de vermicomposta.}

Table 3. Fruit size of tomatoes produced per vermicompost dose.

\begin{tabular}{ccccccc}
\hline \multirow{2}{*}{ Dosis } & \multicolumn{7}{c}{ Tamaño de frutos en cm } \\
\cline { 2 - 7 } & 4 & 5 & 5.6 & 6 & 6.7 & 7 \\
\hline 4000 & 0 & 32 & 15 & 44 & 0 & 10 \\
2000 & 5 & 39 & 15 & 22 & 3 & 16 \\
1600 & 7 & 38 & 19 & 35 & 0 & 0 \\
1000 & 1 & 16 & 17 & 56 & 2 & 7 \\
500 & 0 & 21 & 21 & 33 & 5 & 21 \\
0 & 0 & 0 & 25 & 45 & 11 & 19 \\
\hline
\end{tabular}

Vermicompost had an effect on tomato weight and size, since the essential nutrients in the applied vermicompost are similar to those reported by Atiyeh et al. (2002) and Shankar et al. (2012), who mention that vermicompost provide the nutrients needed for a good plant development. The structural improvement of the cultivation soil favors the activity of microorganisms, which influence the exchange of nutrients and the plant potential to grow and increase the production volume of tomato (Alarcón and Ferrera-Cerrato, 2000; Arancon et al. 2004, 2006). The nutrients in a medium such as vermicompost are assimilated by the plant in higher concentration since they have greater bioavailability as observed in the present study, thereby supporting plant growth and development in a relatively short time, leading to an earlier onset of fruit formation and production compared to the control plants.

The vermicompost effect on tomato development had an important influence on plant yield, increasing fruit number and weight. Plants with the $4000 \mathrm{~kg} \mathrm{VC} \mathrm{ha}^{-1}$ 
Akanbi, W. B.; Adediran, J. A.; Togun, O. and Sobulo, R. A. 2000. Effect of organic-based fertilizer on the growth, yield and storage life of tomato (Lycopersicon esculentum Mill). Bios. Res. Comm. $12: 439-444$

Arancon,A. Q.; Edwards, C.A.;Atiyeh, R. and Metzger, J. D. 2004. Effects of vermicomposts produced from food waste on the growth and yields of greenhouse peppers. Biores. Technol. 93:139-144.

Arancon, N. Q.; Edwards, C. A. and Bierman, P. 2006. Influences of vermicomposts on field strawberries: Part 2. Effects on soil microbiological and chemical properties. Biores. Technol. 97:831-840.

Atiyeh, R. M.; Arancon, N.; Edwards, C. A. and Metzger, J. D. 2000. Influence of earthworms-processed pig manure on the growth and yield of greenhouse tomatoes. Biores. Technol. 75:175180.

Atiyeh, R. M.; Arancon, N. Q.; Edwards, C. A. and Metzger, J. D. 2002. The influence or earthworm-processed pig manure on the growth and productivity of marigolds. Biores. Technol. 81:103-108.

Chakraborty, B.; Chandra, A. K. and Chakraborty, S. K. 2008. Effect of integrated nutrient supply and growth, leaf yield and field performance of mulberry (Morus alba) under semi irrigated lateritic soil condition of west midnapore district, West Bengal. J. Environ. Socio. 5:221-226.

Chanda, G. K.; Bhunia, G. and Chakraborty, S. K. 2011. The effect of vermicomposting and other fertilizers on cultivation of tomato plants. J. Hortic. Fores. 3:42-45.

Domínguez, J.; Lazcano, C. y Gómez-Brandón, M. 2010. Influencia del vermicompost en el crecimiento de las plantas. Aportes para la elaboración de un concepto objetivo. Acta Zoológica Mexicana. 2:359-371.

Ghosh, M.; Chottopadhya, G. N.; Baral, K. and Munsi, P. S. 1999. Possibility of using vermicompost in Agriculture for reconciling sustainability with productivity. Proceeding of the Seminar on Agrotechnology and Environment. 64-68 pp.

Kale, R. D. 1998. Earthworm: Cinderella of Organic Farming. Prism Books. Bangalore. dose outperformed the plants in the control treatment. Vermicompost can be an excellent complement for chemical fertilizers promoting higher yield and fruit quality for both the national and international market, but an economic analysis is required to consider vermicompost as a viable product for tomato cultivation.

End of the English version

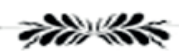

Lazcano, C.;Arnold, J.; Tato,A.;Zaller, J. G. y Domínguez,J. 2009. Compost amd vermicompostas nuersery potcomponents: effects on tomato plant growth and morphology. Spanish J. Agric. Res. 7:944-951.

Maynard, A. A. 1995. Cumulative effect of annual additions of MSW compost on the yield of field-grown tomatoes. Compost Science and Utilization. 3:47-54.

Olivares-Campos, M.; Hernández-Rodríguez, A.; Vences-Contreras, C.; Jáquez-Balderrama, J. L. y Ojeda-Barrios, D. 2012. Vermicomposta y composta de estiércol de ganado vacuno lechero como fertilizantes y mejoradores de suelo. Universidad y Ciencia. 28:27-37.

Orozco,F.H.; Cegarra, J.; Trujillo,L.M. and Roig,A. 1996. Vermicomposting of coffee pulp using earthworm Eisenia fetida: effects on $\mathrm{C}$ and $\mathrm{N}$ contents and availability of nutrients. Biol. Fertility Soils. 22:162-166.

Shankar,K. S.; Sumathi, S.; Shankar, M. and Reddy, N. N. 2012.Comparison of nutritional quality of organically versus conventionally grown tomato. Indian J. Horticulture. 69:86-90.

Togun,A.O. andAkanbi, W.B. 2003. Comparative effectiveness of organicbased fertilizer to mineral fertilizer on tomato growth and fruit yield. Compost Science and Utilization, 11:337-342.

Tomati,U.; Galli,E.; Grappelli,A. andDihena, G. 1990.Effect of earthworm cast on protein synthesis in Radish Raphanus sativum and lettuce Lactuca sativa seedlings. Biol. Fertility Soils. 9:288-289. 